\title{
The Effect of Financial Ratio in Financial Distress with Firm Size as Moderated Variables (Empirical Study of Manufacturing Sector Companies Listed on The Indonesia Stock Exchange for The 2014-2018 Period)
}

\author{
Suharti, Yunita Purnamasari, Ardhyayuda Patria Mahari, Menik Puji Astutik, and Suci Pawiati \\ Master of Management Faculty of Economics and Business, Universitas Diponegoro, Semarang \\ e-mail: yunitapurnamasari993@yahoo.com
}

\begin{abstract}
This study aims to obtain empirical evidence and analyze the effect of financial ratios on financial distress with firm size as a moderating variable. The financial ratios include liquidity ratios that are proxied by Current Ratio, solvency ratios proxied by Debt Asset Ratio, profitability ratios proxied by Return on Assets and Firm Size proxied by the natural logarithm of Total Sales. The population in this study were manufacturing companies listed on the Indonesia Stock Exchange in 2014 - 2018. The total sample used in this study were 85 companies based on established criteria. Data analysis was performed by binary logistic regression and Moderated Regression Analysis. The results of the analysis of this study indicate that the Current Ratio, Debt Asset Ratio and Return on Assets have a significant negative effect on financial distress. The results of the Moderated Regression Analysis reveal that firm size has a significant moderation effect on the relationship between the three independent variables and financial distress in manufacturing companies.
\end{abstract}

Keywords-Financial Ratios, Firm Size, Financial Distress.

\section{INTRODUCTION}

$\mathrm{C}$ OMPANY conditions experiencing difficult times before the company went bankrupt company is Financial Distress. For that vigilance is required to be prepared by management based on the company to not occur in conditions of Financial Distress. The use of financial ratio is the most appropriate measure in penilaian performance of the company and are often used to provide a snapshot of a company the company is healthy or not. To assess whether or not a company's healthy what is commonly used ratio is the ratio liquidity, solvency, profitability and firm size.

Liquidity is the company's ability to pay short-term debt. Companies are more liquid will be spared from experiencing the threat of Financial Distress. Several studies have shown to have obtained different results, Hamid Waqas et al (2018) and Keter Kipkemboi Jackson et al (2018) found that the current ratio of significant positive effect on financial distress while Saleha Azam et al (2017) and Mesak Dance et al (2019) found negative results. Leverage is the ability of companies how to pay off current liabilities and long term debt. This ratio can assess a company is able to finance by using debt. There are differences in the results of keeping research earlier about the influence Leverage against financial distress such as the study of Deden Edwar Yokue Bernadin (2019) and Saleha Azam et al (2017) found that the Debt to Asset Ratio significant positive effect on financial distress while renty Rismawati et al (2017) found negative results.

Profitability shows how a company's ability to earn a profit from sales-related revenue, assets and capital based on specific measurements. Previous studies such as that carried out Hazeem B et al[1] and Eunice Wangare Mburu (2018) obtained results that Return On Assset positive effect on the financial distress while Nurhayati et al (2017) and Mesak Dance et al (2019) found that Return On Assseta significant negative effect on the financial distress. In addition to using financial ratios, financial distress can also be seen by the size of the company with the aim to screen companies can be said to a large or small a number of ways such as by asset sales, the value of the stock market, the average level of sales. In this study, a proxy for firm size using the natural logarithm of total sales according to research from Fredrick Ikpesu (2019) and Praise inten Rianti found positive results between firm size on financial distress while Reta Eminingtyas (2017) stated that the results were different.

Ellouni and Gueyie[2] states that if the company experienced financial distress then associate with the basics seperti has earnings per share were negative. As explained that the information on the show by EPS is considered useful information for a company. Because the EPS information can explain bagaimana prospects for corporate earnings in the future. If a company has Earning Per Share is continuously generating positive in each period will have good growth in the future.

\section{LITERATURE REVIEW}

Empirical literature review on how big the size of the company's financial difficulties influence has yield mixed results and is therefore not clear. While some studies show that larger companies are more likely to suffer financial distress because of their high appetite for debt financing and inefficiency, other studies have postulated that it is a small company vulnerable to financial distress because of their inability to access credit. Furthermore, it has been argued that factors such as economies of scale can reduce the financial 
The $1^{\text {st }}$ International Conference on Business and Engineering Management (IConBEM 2020)

February $1^{\text {st }} 2020$, Institut Teknologi Sepuluh Nopember, Surabaya, Indonesia

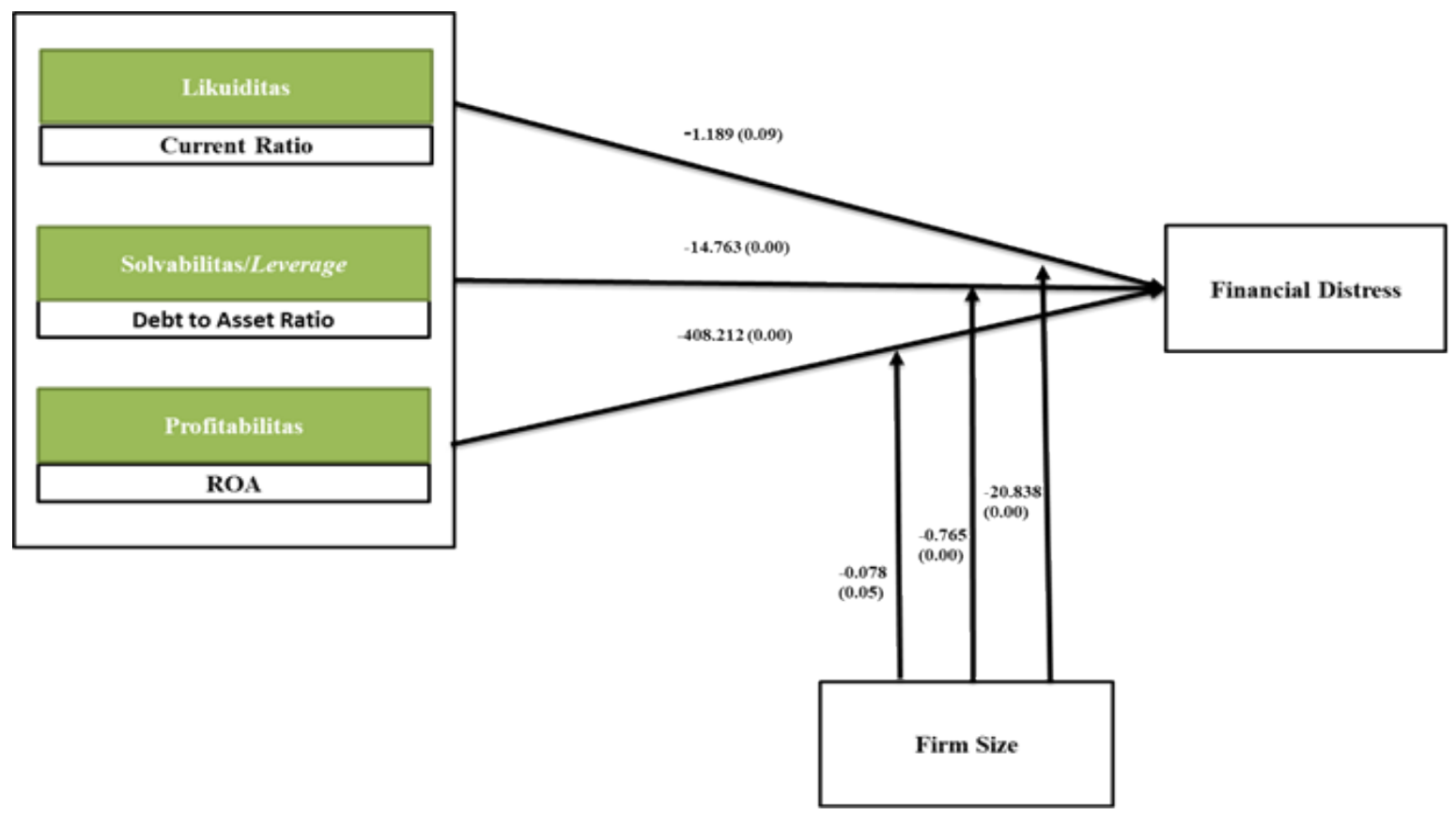

Figure 1. Research Framework and Hypotheses.

impact of the difficulties among large-scale enterprises different from smaller. This is the background of conflicting findings in this study.

\section{A. Liquidity Ratio}

By Fred Weston in Kashmir[3], this ratio shows how the company's ability to meet its short term obligations. Financial liabilities may be payable in the short term, labor wages, payment of electricity bills, water that is equired in the production process, and so on. The Company had liquid assets, namely cash. According to Fahmi Irham (2016: 65) that: "The liquidity ratio is the ability of a company meet its short term obligations in a timely manner. Because the liquidity ratio is often referred to short-term liquidity. "According Breasley, Myers, and Marcus (2008: 78) explains that the current ratio is a ratio to measure how a potential company can manage the company's cash reserves. Current Ratio can be calculated using the following formula:

Current Ratio $\quad: \frac{\text { Current Asset }}{\text { Current Liabilities }}$

\section{B. Solvabilty / Leverage Ratio}

Leverage ratio is the ratio to measure how the assets of companies able to finance the company's debts). The leverage ratio is also able to measure how companies make payments throughout the debts, both short-term debt and long-term debt if the company will be liquidated. Brigham \& Houston (2010: 143) explains that the preferred creditor if the debt ratio is minimal because it can lead to the amount of protection for creditors if the liquidated damages. This ratio explains that the leverage ratio is able to measure the percentage of funds provided from creditors. The ratio is calculated by the following formula:

Debt to Asset Ratio $\quad: \frac{\text { Total Debt }}{\text { Total Asset }}$

\section{Profitability Ratio}

Ratios Profitability is the company's ability to utilize all capabilities and resources exist to profit. This course is very important for long-term investors when analyzing the profitability. In this study using ROA (Return on Assets). If the ratio is lower ROA shows that the ability of the company is less productive in generating profits. This condition is compounded if less productive finance company. Internal funding sources in the investment will lead to the likelihood of financial distress. Here ROA with the following formula:

Return On Asset $\quad: \frac{\text { Net Profit }}{\text { Total Asset }}$

\section{Firm Size or Company Size.}

According Wiwin and Dani (2017), the size of the company is the classification of companies including large or small company. Companies that have a large total assets able to classification and be less likely to bankruptcy. In addition, the size of the company can was measured by total net sales. That the higher the sales of a company, the greater the size of the company and the company is said to be stable and reduce the likelihood of financial distress. In this study, researchers used in measuring the company's total assets. The formula can be calculated as follows:

\section{Firm size $=$ Ln Total Revenues}

\section{Financial Distress}

According Elloumi and Gueyie[2], financial distress is defined if the company has earnings per share were negative. 
The $1^{\text {st }}$ International Conference on Business and Engineering Management (IConBEM 2020)

February $1^{\text {st }} 2020$, Institut Teknologi Sepuluh Nopember, Surabaya, Indonesia

Table 1

Descriptive Statistics

\begin{tabular}{|c|c|c|c|c|c|}
\hline & \multicolumn{3}{|c|}{ NMinimum maximum } & mean & Std. de \\
\hline $\mathrm{CR}$ & 299 & .02 & 5.82 & 2.0 & \\
\hline DAR & 299 & .04 & 20:01 & & \\
\hline ROA & 299 & -.44 & .30 & & \\
\hline $\begin{array}{l}\text { Valid N } \\
\text { (listwise) }\end{array}$ & 299 & & & & \\
\hline
\end{tabular}

Table 2.

Variables in the Equation

\begin{tabular}{crrrrrrr}
\hline \multicolumn{8}{c}{ ariables in the Equation } \\
\hline Step 1a CR & \multicolumn{1}{c}{ B } & \multicolumn{1}{c}{ SE } & Wald & df & \multicolumn{2}{c}{ Sig. } & Exp (B) \\
DAR & -1189 & .701 & 2,878 & 1 & .090 & .304 \\
ROA & -408212 & 117252 & 12 & 12121 & 1 & .000 & .000 \\
Constant & 6,197 & 3,213 & 3,720 & 1 & .054 & 491485 \\
\hline \hline
\end{tabular}

a. Variable (s) entered on step 1: CR, DAR, ROA.

Table 3.

Variables in the Equation

\begin{tabular}{crrrrrrr}
\hline \hline & \multicolumn{2}{c}{ B } & \multicolumn{2}{c}{ SE } & Wald & df & \multicolumn{2}{c}{ Sig. } & Exp (B) \\
\hline Step 1a CRM & -.078 & .040 & 3,809 & 1 & .050 & .925 \\
Darm & -.765 & .220 & 12089 & 1 & .001 & .465 \\
ROAM & -20838 & 6,026 & 11957 & 1 & .001 & .000 \\
Constant & 6477 & 3,256 & 3,957 & 1 & .047 & 649936 \\
\hline \hline
\end{tabular}

The ratio is most often used by the principal in assessing the prospects of the company in the future compared to other financial ratios.

Same thing with Tandelilin nay, 2011, which said that the information provided by the earnings per share is the most basic information to describe the outlook for earnings in the company's future. Under these conditions if the company will have difficulties to obtain funds that can lead to bankruptcy. Thus, this study used Earning per share. Because the companies that have good growth in the future if it has earnings per share (EPS) is continuously positive in every period. Otherwise, EPS negative in some periods depict poor profit outlook and also the growth of companies that are less attractive to investors. With the following formula:

Earning Per Share $\quad: \frac{\text { Net Income }}{\text { Total Outstanding Shares }}$

\section{RESEARCH FRAMEWORK AND HYPOTHESES}

Hypothesis $1:$ Liquidity have a negative effect on financial distress hypothesis 2 : Leverage have a positive effect on financial distress hypothesis 3 : profitability have a negative effect on financial distress

Hypothesis 4 : Firm size strengthening the influence of liquidity in financial distress hypothesis 5 : Firm size strengthening the influence of leverage in financial distress hypothesis 6: Firm size strengthening the influence of profitability in financial distress. (Fig. 1)

\section{RESEARCH METHODOLOGY}

\section{A. Data}

Research will be carried out using the type of secondary data. Secondary data is obtained from the publications or other sources. Secondary data were used to analyze every variable that can be related to each other. In this study, obtaining the data from the financial statements manufacturing company located in Indonesia Stock Exchange in 2014-2018, namely www.idx.co.id.

\section{B. Sample and Population}

The population in this study are all the Companies in the Manufacturing Sector listed in Indonesia Stock Exchange in the period $2014-2018$ is known that there are 123 listed companies Manufacturing in the period 2014 - 2018. The sample selection is done by purposive sampling technique. Purposive sample selection technique is taken with a specific purpose. This technique aims to obtain a sample in accordance with predetermined criteria. The criteria that the intent is:

Manufacturing Company listed in Indonesia Stock Exchange (BEI) in the period 2014-2018.

1. Manufacturing company doing the publication of the annual financial statements audited by an independent auditor

2. The Company publishes financial statements that provide all the required data regarding the study variables, namely liquidity ratios, leverage ratios, profitability ratios, and firm size.

\section{Test Descriptive Statistics}

The tests used in this study was to determine the results of the results obtained by the descriptive data such as for example the amount of data, average, standard deviation, as well as the highest and lowest figures. This can be seen through a tabular summary of the data in the input.

\section{Hypothesis Testing}

In this study, researchers used the approach with binary logistic regression method. This method is carried out due to test whether there is the influence of the independent variable on the dependent variable in the form of dichotomies or binary variable. According Ghozali[4], binary logistic regression analysis techniques are not necessary to test and classical assumption of normality on the independent variable. In the binary logistic regression testing can be viewed from several trials, namely:

1. Hosmer and Lemeshow's goodnes of Fit of assessing the feasibility of a logistic regression model.

2. Overall Model Fit comparing -2 Log Likelihodd (-2LL).

3. Nagelkerke's R Square that assessment coeficient determination.

4. Classification table to show the predictive power.

5. Test multicoloniarity

If there is the influence of the independent variable to variable dependent then shown by the results of significant value which amounted to the level of 0.05 or $5 \%$. Therefore, in this test required criteria:

a. If the hypothesis is accepted, the necessary result of significance for $\mathrm{sig}>0.05$, or $5 \%$.

b. If the hypothesis is rejected then the required results of significance for $\operatorname{sig}<0.05$ or $5 \%$.

c. If you see a positive direction can be determined if the beta value is positive, but also to see the value of sig $<0.05$.

d. If you see a negative direction can be determined if the beta value is worth the negative as well but to see sig $<0.05$. 
The $1^{\text {st }}$ International Conference on Business and Engineering Management (IConBEM 2020)

February $1^{\text {st }} 2020$, Institut Teknologi Sepuluh Nopember, Surabaya, Indonesia

The equations used in this study are:

Model a $: \log =\alpha-\beta 1(\mathrm{CR})+\beta 2(\mathrm{DAR})-\beta 3(\mathrm{ROA})\left({ }^{\pi \mathrm{j}}\right)$

$1-\pi \mathrm{j}$ Model $\mathrm{b}: \log \left({ }^{\pi \mathrm{j}}\right)=\mathrm{A}-\beta 1(\mathrm{CR})+\beta 2(\mathrm{DAR})-\beta 3(\mathrm{ROA})$

$-\beta 4(\mathrm{CRM})+\beta 5(\mathrm{Darm})-\beta 6(\mathrm{ROAM})$

$1-\pi \mathrm{j}$

Information:

1) Test the feasibility of the model

In testing the feasibility of a regression model seen by testing the Hosmer and Lomeshow's goodnes of Fit Test. If in testing Hosmer and Lomeshow's goodnes of Fit Test results are less than or equal to 0.05 , then the hypothesis is rejected, which means the model Hosmer and Lomeshow's goodnes of Fit Test inaccurate in predicting the observed values. Meanwhile, if the testing Hosmer and Lomeshow's goodnes of Fit Test results are more or equal to 0.05, which means that the hypothesis accepted model of Hosmer and Lomeshow's right goodnes of Fit Test to predict the observed values. Assessing the overall models (overall model fit).

Hypothesis testing using likelihood L which is the possibility that the model can be hypothesized from inputted data. In testing the hypothesis that the L transformed into $2 \operatorname{LogL}$ ie derivatives of the likelihood of $\mathrm{L}$. If the regression model indicated by the results of $2 \operatorname{LogL}$ that means is made in the hypothetical model fit to the data.

2) The coefficient of determination (R Nagelkerke Square)

This test measures the size imitating R2 on a multiple regression based on likelihood estimation techniques with a maximum value of less than 1 (one) so difficult to Interpret. Nagelkerke R Square is a modification of the coefficient Cox and Snell Square to ensure that the existing value varies from 0 (zero) to 1 (one). The means used are dividing the value of Cox and Snell Square on multiple regression. A small value of the dependent variable explained variation is limited while a value close to the information needed to explain the variability of the dependent variable.

\section{3) Classification matrix}

Predicting the probability of an enterprise of their financial distress can be seen by the power of the regression model.

\section{RESULTS AND DISCUSSION}

Descriptive statistical analysis is presented to give general information about the characteristics of the sample in the form of the highest value, lowest value, standard deviation, and median. Results analytics descriptive statistics presented in the Table 1.

Based on Table 2 can be seen that the liquidity variable (X1) has a minimum value of 0.02 and a maximum value of 5.82. leverage variable (X2) has a minimum value of 0.04 and a maximum value of 20:01. profitability variable (X3) has a minimum value of -0.44 and a maximum value of 0.30 .

Based on the Table 3 when the independent variable of the liquidity ratio (X1) and leverage (X2), and profitability (X3) contributed (constant) to the dependent variable, namely financial distress. $T$ statistical tests performed to determine whether partially independent variables affect the dependent variable. Based on Table is known that the current ratio has a value of $-1.189 \mathrm{t}$ with a significant level of 0.09 which means greater than significant level of 0.05 . These results indicate that the current ratio of no effect on the financial distress. Variable debt to total assets ratio has a value of $-14.763 \mathrm{t}$ with a significant level of 0.00 which is smaller than the significant of 0.05 . These results indicate that the ratio of debt to total assets negatively affect the financial distress.

Variable interaction between current ratio and firm size has a t value of -0.78 with significant level of 0.050 which equates with a significant level of 0.05 which indicates that firm size as moderating variables can affect partially in financial distress. Variable interaction between debt to total assets ratio and firm size has a $t$ value of -.765 with a significant level of 0.01 , which means smaller than the significant level of 0.05 , which indicates that firm size as the moderating variable can be partial effect on the financial distress. Variable interaction between return on assets and firm size has a value of -20.838 with a significant level of 0.01 , which means smaller than the significant level of 0,00 . (Table 3 )

\section{CONCLUSION}

The study found that debt can reduce the risk of financial distress in manufacturing companies listed in Indonesia Stock Exchange in 2014-2018. Based on these findings, the study concluded that the size of the company has a significant moderating effect on the relationship between liquidity, solvency, profitability and financial difficulties in the manufacturing companies listed in Indonesia Stock Exchange in 2014-2018.

\section{REFERENCES}

[1] H. B. Al-khatib and A. Al-Horani, "Predicting financial distress of public companies listed in Amman stock exchange," Eur. Sci. J., vol. 8 , no. 15 , pp. $1-17,2012$.

[2] F. Elloumi and J. Gueyié, "Financial distress and corporate governance: an empirical analysis," Corp. Gov. Int. J. Bus. Soc., vol. 1 , no. 1, pp. 15-23, 2001

[3] K. Kasmir, Analisis Laporan Keuangan. Jakarta, Indonesia: RajaGrafindo Persada, 2008.

[4] I. Ghozali, "Analisis Multivariate dengan program IBM SPSS 19," Semarang Badan Penerbit Fak. Ekon. Univ. Diponegoro, 2011. 